\title{
DEALING WITH SDG'S COMMITMENT ON SUSTAINABLE CITY DEVELOPMENT: THE PROBLEMS OF MUNICIPAL WASTE OF SIDOARJO
}

\author{
Muhammad Kamil \\ kamil@umm.ac.id \\ Department of Government Studies, Faculty of Social and \\ Political Sciences, University of Muhammadiyah Malang \\ Demeiati N. Kusumaningrum \\ demeiati.kusumaningrum@gmail.com \\ Department of International Relations, Faculty of Social and \\ Political Sciences, University of Muhammadiyah Malang
}

\begin{abstract}
The target of sustainable development - the Sustainable Development Goals (SDGs) Achieved in 2030 is the agenda of Governments around the world based on the resolution of the general assembly issued. The government has shown strong commitment and taken initial action, Including connecting most SDGs targets and indicators into the national medium-term development plan (RJPMN). This research focuses on local government in Realizing the goals of the SDGs, especially the 11th targets on sustainable city development. Sidoarjo has the strategic economic and social potential as the highest industry revenue contributor in East Java. Meanwhile, as a representation of the industrial cities, Sidoarjo faces problems of urban waste. Sidoarjo, the which has received 8 (eight) Verse awards, was finally criticized by the community of environmentalists. Given that urban environmental problems are Believed to influence the legitimacy of the local government. This study uses a qualitative descriptive approach that is intended to explore information about the role of local Governments in Realizing the concept of sustainable urban development that focuses on waste management and mitigation of river pollution. This research primary and secondary uses of data types. Primary Data is the result of interviews from research subjects who are interested parties in Sidoarjo RAN, Including Bappeda, DLKH and PUPR. Secondary Data is Obtained from the results of a literature review of local government Several report documents, journals related to the implementation of SDGs and other scientific sources. In an effort to deal with urban waste problems, the Government of Sidoarjo City Applies Several strategies to Achieve urban sustainability. First, the Environmental Agency and the Public Works Agency Carried out the construction of a Sanitary Landfill as an environment-based waste treatment. Second, in Achieving Zero Waste in Sidoarjo City, the government involves sub-districts as stakeholders in regional-based waste management.
\end{abstract}

Keywords: Industry, Local Government, Municipal Waste, Sustainable City Development 
Proceeding ICOGISS 2019

Page 338-350. ISBN: 978-602-6 988-75-1

Web Jurnal Online: jurnal.unmuhjember.ac.id

By: Muhammad Kamil and Demeiati N. Kusumaningrum

Dealing With Sdg's Commitment On Sustainable City Development: The Problems Of

Municipal Waste Of Sidoarjo

\section{A. Introduction}

Post international development cooperation to overcome poverty, known as the Millennium Development Goals (MDGs) by 2000 to 2015, the countries agreed on a new format to enhance the target has been achieved through sustainable development targets, called Sustainable Development Goals (SDGs). According to the United Nations (UN), the difference lies in the MDGs and SDGs new targets calling for action by all countries of all income levels to improve the well-being while protecting the earth. The international community realize that poverty reduction must go hand in hand with economic growth strategies that build and answer various social needs including education, health, social protection, and employment opportunities, while addressing climate change and environmental protection.

Spirit of sustainable development partnership agreement is to strengthen universal peace understood as freedom from the pressures of poverty. The UN also said that poverty has a broad meaning and multidimensional. So expect all parties both public and private, are able to move collaboratively to improve the common welfare by not subjecting the environment and habitat in it (UN, 2015), "The main principle of the sustainable development agenda is the inclusion and participation. In addition to the consultation, various platforms are needed at national and local levels that will bring together governments, investors, corporations, philanthropy, civil society and academia and to encourage a real partnership. "(Bahuet \& Sopacua, 2018)

As quoted in the UCLG (2018), there are 17 Sustainable Development Goals and sustainable development targets 169 integrated and balance the three dimensions include economic, social and environmental. Target 1) Eradicate poverty a halve the proportion of poor people nationwide in 2030. The poor are the people of both women and men, living under \$ 1.25 per day. This one talks about increasing income for the poor, ensuring access to basic services and protect the entire community from all forms of disaster. Target to 2 speaks of overcoming hunger around the world. This is so that all people can enjoy a nutritious meal. The Government shall pay attention to the achievement of food security, nutrition, and support for sustainable agriculture.

Furthermore, the target SDGs to 5 refers to the elimination of discrimination and violence against women and girls, as well as ensure that all women have the same opportunities in all aspects of life. This is emphasized through the implementation of gender equality and women's empowerment. Target to 6 aims to ensure access to clean water and sustainable sanitation for the entire community. Meanwhile, the target to 7 pay attention to the entire community access to energy that is affordable, reliable, sustainable and modern. Target to 8 talk about increasing decent employment and economic opportunities for all. This is done through inclusive economic growth and sustainable development, full employment and productive.

Target to 11 SDGs talking about bringing towns and settlements are inclusive, secure, resilient, and sustainable. The purpose of this target is about how to position the cities at the core of sustainable development in the midst of rapid urbanization. Target to 12 is talking about reducing the environmental impact to the earth through the patterns of 
Proceeding ICOGISS 2019

Page 338-350. ISBN: 978-602-6 988-75-1

Web Jurnal Online: jurnal.unmuhjember.ac.id By: Muhammad Kamil and Demeiati N. Kusumaningrum Dealing With Sdg's Commitment On Sustainable City Development: The Problems Of Municipal Waste Of Sidoarjo

production and consumption perspective. It is expected that the countries in 2030 were able to manage natural resources efficiently and sustainably.

Thus, the target of sustainable development into national policy platform also become the target of local governments in Indonesia. It takes SDGs integration into regional development plans at provincial and district levels. Based on Presidential Decree No. 59 in 2017, local authorities should develop the Regional Action Plan to integrate objectives, targets and indicators SDGs into the Medium Term Development Plan.

Model of urban development and partnerships between governments and companies through CSR successfully promoting some thematic innovation RTH and increase social benefits of green open spaces in the city of Malang. This policy is aimed at creating long-term environmental well-being, while still accommodating communication, interaction, social integration, and improving the quality of health all elements of society (Kurniawati, Kusumaningrum, \& Haffsari, 2017),

Meanwhile, the government of Bandung and Surabaya paying attention to the concept of "smart city". Smart city by the mayor of Bandung is defined as "the use of information and communication technology (ICT) to connect, monitor and control the various resources available in the city effectively and efficiently to maximize service to the citizens". City government focused on the renewal of the 10 (ten) the sector include; 1) governance, 2) education, 3) transport, 4) health, 5) energy, 6) security, 7) environment, 8) community/ social, 9) financial system, and 10) trading(Kamil, 2015; Utomo \& Hariadi, 2016),

Furthermore, the Surabaya city government is also working to integrate ICT in public services. Surabaya City Government Communications and Information Technology Department try to facilitate all the IT needs of its citizens to be IT literate as well is expected to produce the information content, so that it can contribute to the development of the city. The agency provides free internet facilities in 42 points in Surabaya city park that can be accessed citizens for 24 hours. The goal is that the people of Surabaya easier to obtain a variety of information online(Ulfa, 2016),

This study focuses on local governance in realizing the purpose of SDGs, in particular the target to 11. The results of the congress, held 13 September 2018 in Surabaya, shows the commitment the members of UCLG Asia Pacific to contribute proactively to the new global partnerships between international organizations, governments national, public, and private sectors. At the opening of this meeting the mayor of Surabaya expects all members of the cooperative framework to solve common challenges by promoting innovation in creating sustainable urban and livable. Obviously, a lot of urban problems faced by local governments in the form of waste management, sanitation, drainage, transportation, education, health, housing, poverty, water supply and licensing as well as the handling of the disaster (Centro One, 2018),

Government Batu and Malang have the same problems related to the needs of industrial upgrading to the environmental impact. Batu City is a recreational destination area that relies 65 percent of its revenues in 2012 in the tourism industry. Activity of tourist visits certainly have an impact on the accumulation of garbage increased $10 \%$ each of the weekend. While the administration of Malang Regency experiencing problems of 
Proceeding ICOGISS 2019

Page 338-350. ISBN: 978-602-6 988-75-1

Web Jurnal Online: jurnal.unmuhjember.ac.id By: Muhammad Kamil and Demeiati N. Kusumaningrum Dealing With Sdg's Commitment On Sustainable City Development: The Problems Of Municipal Waste Of Sidoarjo

river water quality degradation caused by the activity of the manufacturing industry. Through the government's policy on sustainable development, both Batu Government and Malang district government has to coordinate and build a series of policies to tackle these problems. Batu city government invested substantial funds for the revitalization of the treatment of waste and litter in the area of Malang Tlekung while district governments focus on strengthening the capacity of the Watershed Processing Office as well as improving sewage treatment socialization related regulations and oversight of the companies in the industrial area(Kusumaningrum \& Haffsari, 2017),

This study focuses on the local government under the leadership Sidoarjo Regent and Vice Regent Syaifullah Nur Ahmad Syafuddin. Sidoarjo used as a model representation in East Java industrial town that is also facing the problem of municipal waste. In addition, several rivers in the Sidoarjo region polluted by garbage and thus potentially interfere with public health, destroying the beauty and water quality(Taufik, 2018), Sidoarjo which has gained 8 (eight) times Adipura ultimately criticized by environmentalists and community(Syairwan, 2017),

Meanwhile, Sidorajo have economic and social potential is quite strategic. This region is the highest contributor to industry revenues in East Java. In Table 1.1. we can see that, the town of Sidoarjo reliable contributor to earnings in the industrial sector. In addition, the industrial development policy in East Java on the fifth point, referring to the facilitation efforts of research and development for the manufacturing industry production technology, including the development of production management which shall take into account environmental sustainability and environmentally friendly production techniques(Disperindag East Java, 2011).

Table 1.1. Number of Large and Medium Manufacturing Company in East Java by Regency / City in 2015

\begin{tabular}{|c|c|c|}
\hline Ranked & County town & amount \\
\hline 1 & Sidoarjo & 978 \\
\hline 2 & Surabaya & 957 \\
\hline 3 & Pasuruan & 811 \\
\hline 4 & Gresik & 603 \\
\hline
\end{tabular}

Source: The Central Bureau of Statistics (BPS East Java, 2018)

Thus, interesting to analyze the efforts of local authorities achieve a balance between the needs of economic, social, and environment in the middle of the demands of industrial progress that became one of the areas of excellence. Given, urban environmental problems are believed to influence the legitimacy of the local government.

\section{B. Sustainability Ecology and Sustainable Development Concept Realization}

The concept of sustainable urban development is defined by the various interpretations of the policy by the municipality or sub-national. This is influenced by the conceptual basis of understanding "what is the meaning of sustainable development" and 
Proceeding ICOGISS 2019

Page 338-350. ISBN: 978-602-6 988-75-1

Web Jurnal Online: jurnal.unmuhjember.ac.id By: Muhammad Kamil and Demeiati N. Kusumaningrum Dealing With Sdg's Commitment On Sustainable City Development: The Problems Of Municipal Waste Of Sidoarjo

"the characteristics of the urban community needs". There are some cities that understand the context of sustainable development that suit the needs of the urban community will be digital communications networks and the spread of Internet-based information that surfaced with the 'smart city' or 'cyber city'. Furthermore, 'smart city' is also supported by the readiness of the elements of the city / county to apply service-based information technology (IT) or the so-called 'e-government'. Furthermore, government policies in realizing the concept of sustainable development based on the "characteristics of the needs of the urban community" certainly should not ignore the economic prosperity, environmental sustainability, and social interests of the international community in accordance with the agreement SDGs targets.

In achieving the target to 11 SDGs to make towns and settlements are inclusive, secure, resilient, and sustainable and amid rapid urbanization, Sidoarjo Municipal Government to make efforts to reduce the environmental impact to the earth through a pattern of a local action plan.

\section{Strategic Planning in Industrial Waste Pollution Control}

The problem of river pollution by domestic sewage and industrial waste occurred in various cities in the world. If we recall, the impact of the industrial revolution in Europe also contributed to environmental degradation. One of them polluting the rivers and lakes. Environmental issues were first raised as an international agenda in 1972 the United Nations Conference on the environment in Stockholm, Sweden. The conference declared that required their shared vision and common principles to be able to guide the world community to preserve the environment (Siahaan, 2004: 143). While the new environmental issues gained recognition among scholars of international relations in the late 1980s. Some scholars who study international environmental policy since the 1980s the Oran R. Young, Kay and Jacobson, and Lynton Keith Caldwell (Carlsnaes et al, 2013).

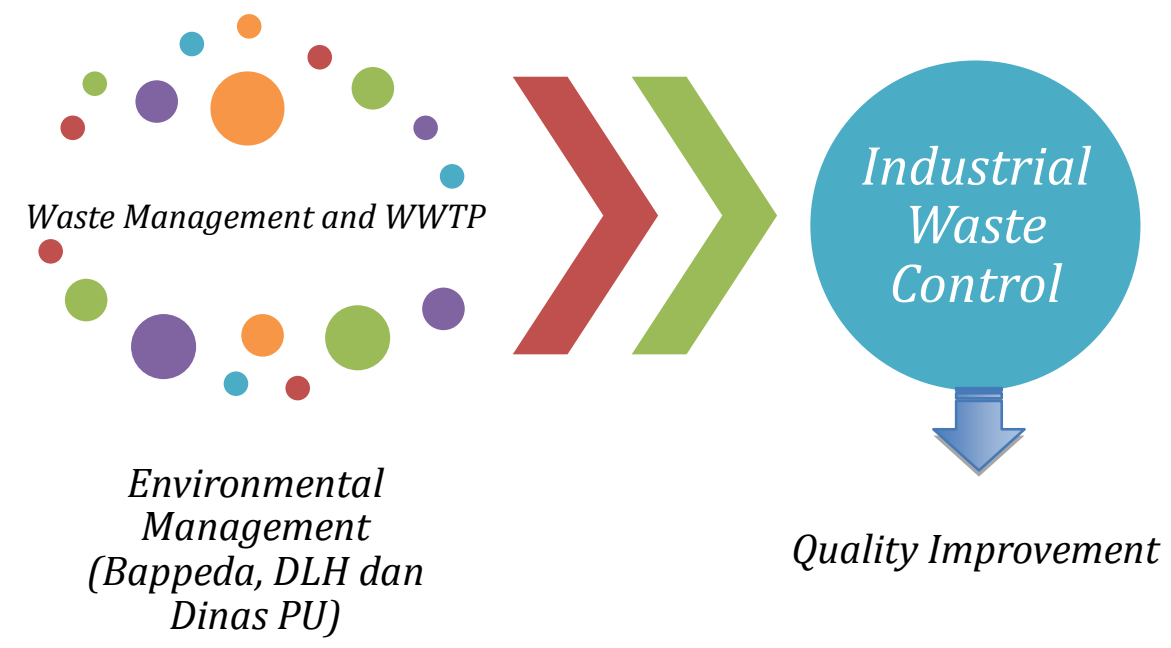

Figure4.1 Model of networking Industrial Waste Control Sidoarjo Regency 
Proceeding ICOGISS 2019

Page 338-350. ISBN: 978-602-6 988-75-1

Web Jurnal Online: jurnal.unmuhjember.ac.id

By: Muhammad Kamil and Demeiati N. Kusumaningrum

Dealing With Sdg's Commitment On Sustainable City Development: The Problems Of

Municipal Waste Of Sidoarjo

Many industries in Sidoarjo the approximately 1,000 pieces and will continue to increase every year, is certainly the waste produced by industry is also growing. Therefore, to encourage the industry players both large-scale industry, medium and small care for the environment and reducing water pollution caused by the waste that is not disposed of carelessly and without treatment processes, the Government of Sidoarjo regency made various efforts to one of them held a Technical Assistance, Toxic Substances Hazardous Waste (B3). This is because the most abundant waste polluting the river or water is B3. Through this bimtek, is expected to grow awareness of environmental concerns in their respective businesses. In addition to holding bimtek, Sidoarjo regency government also maximize the performance of the Waste Water Treatment Plant (WWTP). Through WWTP, waste from industrial activities will be treated with the right process so that the water processing results which have met the environmental quality standards can be used and reused for other activities. Water that has been through the treatment process in the WWTP was cleared and safe to use and no longer contains substances harmful to the environment or human.

Based Sidoarjo Regent Regulation No. 14 of 2016 on the management of hazardous and toxic waste in Sidoarjo, in Chapter II, Article 3 states that any entity that stores and collecting B3 waste must have a permit from the Regent. It thus facilitate the government in its efforts towards waste management and oversight. As for the business entity that does not have permission, or in violation of a predefined permission, it can be either an administrative sanction, a reprimand or sanction in any other form. Until now, the Government of Sidoarjo District continues to promote the commitment of the management permit lmbah toxic and hazardous substances (B3), and to facilitate the process of the current Government of Sidoarjo regency through the Department of Investment and Integrated Services One Stop (DPMPTSP) provides licensing process online through the website DPMPTSP own.

In addition to the management and supervision, the Government also has a responsibility to exercise control over the waste as setting the standard for enterprise or industry that has the potential to produce waste. Standard is meant to be the making of spatial plan (RTRW) that industrial development had no impact on residential or other spaces dedicated to the preservation of the environment, requires that every business or industry to have a license before setting up a business such as the Environmental Impact Assessment (EIA), environmental Management Program monitoring efforts environment (UKL/ UPL) and Statement of environmental Management (SPPL), placed restrictions on the levels of harmful in the production process and must comply with the quality standards of waste, conducting studies on the environment, as well as set a minimum standard of environmental pollution. Then, when a company or industry has been running, the local government can monitor and evaluate the performance of waste management carried out by the enterprises or industries such as conducting environmental audits regularly and perform inspections of business entities or industry complaints by the people because of their potential or activities that have an impact on environmental pollution. If the two activities mentioned above can be run optimally, it 
Proceeding ICOGISS 2019

Page 338-350. ISBN: 978-602-6 988-75-1

Web Jurnal Online: jurnal.unmuhjember.ac.id By: Muhammad Kamil and Demeiati N. Kusumaningrum Dealing With Sdg's Commitment On Sustainable City Development: The Problems Of Municipal Waste Of Sidoarjo

can reduce the environmental pollution caused by waste. However, if in fact, still a lot of waste that pollute the environment even though it has held two of the above activities, the Government may do next action is to do the repairs.

Recovery from waste pollution can not be done easily and in a short time, the potential for success is unpredictable. Therefore, the process of management and supervision should be optimized as much as possible. The remediation efforts can be done to cope with the polluted environment caused by waste is when the area contaminated waste included in the category are very dangerous, so the government should close the area and evacuated local residents to a safer place, if the sewage water polluting the government should appealed to people not to use the water and provide clean water and proper use to be used by the community, providing strict sanctions to businesses or industries that have been polluting the environment and do not manage their waste appropriately, to tighten the process of licensing and supervision for businesses, and to improve the facilities and infrastructure of waste management.

Through this remedial action is expected to reduce the amount of waste and increasing awareness of businesses to be more concerned about the environment. Every business must realize that not only the production to be improved, but concern for the environment should also participate upgraded. Because the waste is mainly waste containing material bercaun hazardous (B3) is a very bad impact to good environmental water, soil and air, and when the environment has been contaminated by the content of these dangerous and exposed or accidentally consumed by humans, can damage health and cause various diseases such as diarrhea, hepatitis, physical disability, mental damage to the cause of death. Therefore, protecting the environment is not only the responsibility of businesses, governments but also the responsibility of the community because the greatest impact is felt the community.

One of the sources of water are being used to meet the needs of human life and living creatures is the river. River water out of the springs usually have a very good quality (Hamakonda, Suharto, and Susanawati, 2019). The river has ekohidrologi function, where the river fishery products capable of supporting national food security. For industry and agriculture, river water also plays an important role in the manufacturing process, as a source of electric power and irrigation. Furthermore, the waters become a major resource for households that serves as drinking, bathing, and washing. In some cities in the world, the river is also a means of transport and developed as a tourist destination (Zaini et al, 2010; Mahyudin et al, 2015; Sharfina et al, 2016; Ward, 2017; Mulyanto and Dharmawan, 2017; Shafii et al, 2018).

The decline in water quality caused by pollution of domestic sewage and industrial waste is not just a problem of ecological but also economic, political, and social. Therefore, pollution of the river become a crucial issue in Indonesia.

\section{Waste Management System Based Sanitary Landfill (SLF)}

In addition industrial development resulted in increased economic growth and development of the city, but on the other hand also have a negative impact on environmental degradation such as air pollution, reduction of soil functions to water 
pollution. The main factors which influenced the decline in water quality and soil is the result of industrial waste carelessly discarded without treatment processes. Until the year 2017, there were 309 industrial counted 690 large and medium industries spread across 19 districts in Sidoarjo. In addition for their industrial waste, pollution of water and soil quality is also caused by the careless disposal of trash or misplaced. In 2018 the number of people in Sidoarjo has reached 2,183,682. The increase of population is of course proportional to the increasing amount of waste particularly household oath.

In 2019, the amount of household waste produced by residents of Sidoarjo regency reached 2,400 tons / day. Of these, only 600 tons, which can be managed well by the government and another 1,800 tons of which can not be processed properly and eventually disposed of carelessly as in vacant lots, on the street, until dumped into rivers that lead to water pollution. The amount of waste mentioned above also does not include litter from industrial and other waste types. If no immediate action by the Government, then the water and environmental pollution will only get worse and will affect the sustainability of the City. Sidoarjo District Government through the Department of Environment and Hygiene (DLHK) has made various efforts, one of which is to build and optimize the Integrated Waste Disposal Sites (TPST) and landfill (TPA). Until 2019, the number has reached 136 TPST TPST spread over 18 districts in Sidoarjo. TPST itself is a building that is used to process and sort the waste which would then be disposed of to landfill. TPST built on the ground the village treasury (TKD) because the government trouble finding land due to land in Sidoarjo district is getting narrower and empty fields others have been earmarked for development and investment. TPST existence is expected to realize the waste sent to landfill was $0 \%$. But the facts that occurred in the field TPST only able to manage as much as $30 \%$, so $70 \%$ is sent to landfill. Therefore, Sidoarjo District Government target by 2025 the amount of waste that goes into landfill is only $30 \%$. To accelerate the achievement of these targets, in some TPST also equipped with a garbage sorter tool that impacts more effective and efficient waste sorting process.

Regarding landfills (TPA), Sidoarjo regency currently has only one landfill is still active, namely landfill in the village of Kupang District of Jabon (TPA Jabon). Jabon landfill has an area of 8 hectares (ha) with a capacity of 400 tons / day. Therefore, to increase the landfill capacity Jabon, to expand the area of 5.8 ha is estimated with an area that will reach almost 14 hectares can accommodate as much as 1,050 tons of garbage / day. In addition to the expansion, also efforts to restore the system into the landfill with the model Sanitary Landfill in the program Emission Reduction in Cities Solid Waste Management (ERIC-SWM) is the result of cooperation between the Government of Sidoarjo regency by Central Government (Directorate of Environmental Sanitation Development, Directorate General of Human Settlements, Ministry of Public Works and Housing of the People) and the German Government.

Sanitary Landfill System (SLF) is a neighborhood-based waste processing system using geo-membrane system, the leachate (the result of a mixture of rainwater and heaps of garbage) will not seep into the soil so it does not detract daam or contaminate soil and water quality. Leachate containing compounds which are harmful to the 
Proceeding ICOGISS 2019

Page 338-350. ISBN: 978-602-6 988-75-1

Web Jurnal Online: jurnal.unmuhjember.ac.id By: Muhammad Kamil and Demeiati N. Kusumaningrum Dealing With Sdg's Commitment On Sustainable City Development: The Problems Of Municipal Waste Of Sidoarjo

environment such as hydrocarbons, humic acid, sulfuric, land and error, sodium, potassium, calcium, magnesium, chlorine, phosphates, phenols, nitrogen, and metal compounds. The mixture of these compounds produce a component whose concentration reaches 1000-5000 times higher than the acid water. Therefore, leachate, or often referred to as leacheat this must be treated first with a processing system that should not be arbitrary, namely through the processing system aerobic or anaerobic before the exhaust into the environment because otherwise seep into the soil, it can cause a decrease in water quality and soil because it can lead to contamination. Furthermore, through the SLF system, garbage that has been processed in the future will also be converted into compost. TPA using SLF system is expected to accommodate nearly 10 thousand tons of garbage and can last up to 20 years to come. Powered by sorting garbage in TPST, then the performance of SLF will also be more effective.

In addition to carrying out waste management through TPST development and build a landfill with SLF models, Sidoarjo District Government also perform other efforts such as creating new regulations to reduce the number of plastic waste utilization. It is also a form of waste reduction and handling involving the public as waste producers. Through this regulation the public will be given an understanding of the procedures for waste management and hazard of the garbage itself which is expected to minimize waste production.

Sidoarjo regency government also began promoting community-based waste management system is through the establishment of Waste Bank in each village. The existence of the Bank Trash can be a container of waste management 3R (Reuse, Reduce, Recycle) and can be a source of economy for the community. In addition to the establishment of Waste Bank, one of the innovations of Sidoarjo regency is formed Kampung Educational Trash that is currently located in the Village Sekardangan. Education Kampung Trash is a village which was inaugurated by the Government for having successfully manage the waste and the environment both by means of hydroponics bubidaya development, manufacture craft from waste that has been recycled, making fertilizer from compost and other management efforts. Kampung Waste Education is to serve as a pilot village for other areas in the district of Sidoarjo. Education Kampung Garbage is also a product of Sidarjo Clean and Green program (SBH). SBH is a program initiated by the government to hold environmental awareness activities, educational rides, as well as efforts to change the mindset of the people and to increase public awareness of waste management.

\section{Cooperation among Stakeholders in Environmental Pollution Monitoring actions}

Sidoarjo regency government will prioritize development for economic growth and investment. The main objective of this development is to increase economic growth in Sidoarjo, this development is done dengann pursue the development of all sectors with the potential to be developed, including the industrial sector. However, this condition actually makes Indonesia as a country that can only process but could not 
Proceeding ICOGISS 2019

Page 338-350. ISBN: 978-602-6 988-75-1

Web Jurnal Online: jurnal.unmuhjember.ac.id

By: Muhammad Kamil and Demeiati N. Kusumaningrum

Dealing With Sdg's Commitment On Sustainable City Development: The Problems Of

Municipal Waste Of Sidoarjo

preserve such natural wealth, since the construction is done only think of economic development and does not consider environmental sustainability.

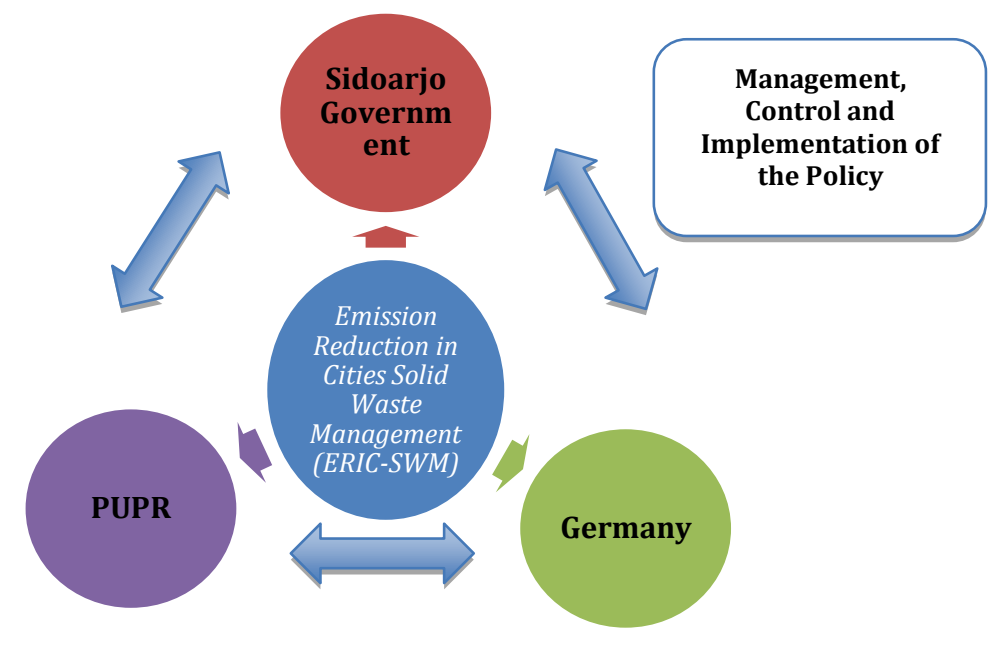

Figure 4.2 Model Cooperation between stakeholders in Waste Management in Sidoarjo

Monitoring and supervision by agencies authorized to exercise control over industrial waste is still based approach to end-of-pipe, which are vulnerable to an inability to cope with in an integrated manner the environmental pollution that can occur in three stages namely stage of the manufacturing process at the business unit, use of the product, as well as the stage after the product is consumed generating waste. The weakness of this approach resulted in environmental damage that occurs in all parts of life.

The number of Government agencies that relate the wastewater pollution control does not make this event run optimally. This happens because of the lack of coordination and communication between the relevant Local Government Organization makes waste pollution control becomes ineffective. The big difference in interest between the WTO to make the communication that exists becomes less than the maximum because when the process of coordination and communication to occur, some OPD does not send a representative to the individual who truly understand the problems and inconsistencies of representatives of the WTO, it makes the information received from the coordination process to be different between one party and the other party.

In carrying industrial waste pollution prevention by conducting environmental permits such as EIA, UKL / UPL and SPPL in every industry in the area of Sidoarjo. This can be evidenced by the number of environmental permits / waste management issued by the Government of Sidoarjo regency, amounting to 270 permits UKL / UPL, 355 permits SPPL, and 6 to permit the EIA. Sidoarjo regency government to perform a service follow up complaints from the public over the target expected by the Ministry of Environment through the Minimum Service Standards for Environment, namely $80 \%$ of the follow-up 
Proceeding ICOGISS 2019

Page 338-350. ISBN: 978-602-6 988-75-1

Web Jurnal Online: jurnal.unmuhjember.ac.id By: Muhammad Kamil and Demeiati N. Kusumaningrum Dealing With Sdg's Commitment On Sustainable City Development: The Problems Of Municipal Waste Of Sidoarjo

service of the complaint. While Sidoarjo able to achieve the target of $100 \%$ in the development of the follow-up handling of public complaints.

Control of physical development to suit the land designation and zoning are not able to do well Sidoarjo regency government. This is evidenced by the number of land-use change request prior to conservation land into land for social and economic activities such as industry. For the industry, in 2011 there were $37.7 \%$ for industrial application for land use of all requests for management land and in 2012 by $31.6 \%$. This makes the development of industry spread throughout areas and does not comply with zoning regulations which have been made in the RTRW document Sidoarjo. In Sidoarjo aspects of implementing the individual response to the implementation of pollution control industrial waste can be seen from the answers given by the informants stated that they did not mind in carrying out all activities and tasks that must be implemented as it relates to public services. Researchers also found several informants who lack understanding about pollution control should be done by Sidoarjo. In addition, the lack of which has a high capability of the environment.

Services of water pollution prevention and the prevention of air pollution by the Government of Sidoarjo district has been unable to achieve the target of the Ministry of Environment in target indicator Minimum Service Standards environmental field. In the target environment SPM national level, water pollution prevention services reached $80 \%$ while Sidoarjo able to implementing up to $70 \%$. As for air pollution prevention services national target of $80 \%$ and Sidoarjo only capable of performing up to $60 \%$ only.

\section{Conclusion}

The handling of the environment in the city of Sidoarjo not just about waste management but also necessary to dealing with the amount of industrial waste causes environmental pollution, especially water pollution. Industrial waste pollution prevention carried out by an audit oversight environment through waste management industry can not be run properly and there are still many industries that pollute. This is because by law enforcement environment is still not firm, so there is no effect on industries that pollute.

Industrial Waste Management and Waste Management System Based Sanitary Landfill (SLF) with a model of networking and cooperation among stakehorders is the recovery efforts of the polluted environment can not be implemented to the maximum. This is due to the lack of green land in Sidoarjo so dirty air absorption becomes less than the maximum. In addition, the recovery program in the region pollution can be resolved. Sidoarjo regency government has not been able to achieve performance targets in suppressing industrial activity that has the potential to pollute. This is evidenced by the performance report in the document LAKIP, where Sidoarjo District Government is not able to realize performance targets that have been planned. 
Proceeding ICOGISS 2019

Page 338-350. ISBN: 978-602-6 988-75-1

Web Jurnal Online: jurnal.unmuhjember.ac.id

By: Muhammad Kamil and Demeiati N. Kusumaningrum

Dealing With Sdg's Commitment On Sustainable City Development: The Problems Of

Municipal Waste Of Sidoarjo

\section{REFERENCES}

Alsoy Toga \& Peride Gonel. (2015). How Green Industry? The Case of Turkey. Worl Journal of Science, Tecnology and Sustainable Development Vol 12. No 2. Emerald Group Publishing

BPS Jatim. (2018). Jumlah Perusahaan Industri Besar dan Sedang di Jawa Timur Menurut Kabupaten/Kota 2013-2015. Retrieved December 10, 2018, from https://jatim.bps.go.id/statictable/2018/04/19/1247/jumlah-perusahaanindustri-besar-dan-sedang-di-jawa-timur-menurut-kabupaten-kota-2013--2015.html

Centro One. (2018, September 13). UCLG ASPAC Dibuka, Tujuan Utama Pembangunan Berkelanjutan. Centro One. Surabaya. Retrieved from http://www.centroone.com/News/Detail/2018/9/13/25515/uclg-aspacdibuka-tujuan-utama-pembangunan-berkelanjutan

Cresswell, John W (2015). Research Design: Pendekatan Metode Pebelitian Kualitatif, Kuantitatif, dan Campuran. Yogyakarta: Pustaka Pelajar.

Disperindag Jatim. (2011). Pelaksanaan Kebijakan Pembangunan Industri Jawa Timur. Surabaya. Retrieved from http://rocana.kemenperin.go.id/phocadownload/Forkom_fungsional/pelaksan aan kebijakan industri di jatim - kadisperindag jatim.pdf

Djeflat. (2010). Sustainabel Knowledge for Sustainable Development: Challenges, Opportunities for African Development. World Journal of Science, Tecnology and Sustainable Development Vol 12. No 2. Emerald Group Publishing

Hendriks, Frank. (2014). Unerstanding good urban governance: Essentials, Shift, and Values. Journal Urban Affairs Review. Vol 50 No 4

Kamil, R. (2015). Smart City Bandung. Retrieved from https://sustainabledevelopment.un.org/content/documents/12659kamil.pdf

Kurniawati, D. E., Kusumaningrum, D. N., \& Haffsari, P. P. (2017). Revitalization of Green Open Space (GOS) in Kota Malang as the Government Response to Urban Social Sustainability. Journal of Sciences and Humanities Research, 2(5), 1-11. Retrieved from https://ijrdo.org/index.php/sshr/article/view/710/666

Kusumaningrum, D. N., \& Haffsari, P. P. (2017). Good Governance for Sustainable Development: Municipal Waste Management. Journal of International and Local Studies, 1(1), 23-30.

Nurmandi, Achmad. (2014). Manajemen perkotaan.Yogyakarta : JKSG

Riant Nugroho, (2009). Public Policy. Jakarta : Elex Media Komputindo

Sugiyono. (2008). Memahami Penelitian Kualitatif. Bandung: CV. ALFABETA.

Sugiyono. (2013). Metode Penelitian Pendidikan (Pendekatan Kuantitatif, Kualitatid, dan $R \& D)$. Bandung: Alfabeta. 
Proceeding ICOGISS 2019

Page 338-350. ISBN: 978-602-6 988-75-1

Web Jurnal Online: jurnal.unmuhjember.ac.id

By: Muhammad Kamil and Demeiati N. Kusumaningrum

Dealing With Sdg's Commitment On Sustainable City Development: The Problems Of

Municipal Waste Of Sidoarjo

Syakrani dan Syahriani. (2009). Implementai Otonomi Daerah dalam Perspektif Good Governance. Yogyakarta: Pustaka Pelajar

Thomas R. Dye, (1987) Understanding Public Policy, Engelewood Chief, New Jersey Prentince-Hall Inc, 1987.

UCLG. (2018). Tujuan Pembangunan Berkelanjutan yang Perlu Diketahui oleh Pemerintah Daerah. Retrieved from https://www.uclg.org/sites/default/files/tujuan-sdgs.pdf

Syairwan, I. (2017, August 2). Sidoarjo 8 Kali Dapat Adipura, Ini Kata Aktivis Lingkungan. Tribunnews. Sidoarjo. Retrieved from http://surabaya.tribunnews.com/2017/08/02/sidoarjo-8-kali-dapat-adipuraini-kata-aktivis-lingkungan

Taufik, M. (2018, May 23). Kondisi Sungai di Sidoarjo Memprihatinkan, Penuh Sampah. Tribunnews. Sidoarjo. Retrieved from http://jatim.tribunnews.com/2018/05/23/kondisi-sungai-di-sidoarjomemprihatinkan-penuh-sampah

UCLG. (2018). Tujuan Pembangunan Berkelanjutan yang Perlu Diketahui oleh Pemerintah Daerah. Retrieved from https://www.uclg.org/sites/default/files/tujuan-sdgs.pdf

Ulfa, E. M. (2016). Pelaksanaan Program Broadband Learning Center (BLC) Oleh Dinas Kominfo Pemkot Surabaya Untuk Mewujudkan Surabaya Cyber City. Sospol: Jurnal Sosial Politik, 2(1), 29-55. Retrieved from http://ejournal.umm.ac.id/index.php/sospol/article/view/4754/4896

UN-Habitat. (2000). The Global Campaign for Good Governance Diakses dari https://www.researchgate.net/publication/294756761 UNCHS Habitat the global_campaign_for_good_urban_governance

UN. Resolution adopted by the General Assembly on 25 September 2015 (2015). General Assembly. $\quad$ Retrieved from http://www.un.org/ga/search/view_doc.asp?symbol=A/RES/70/1\&Lang=E

Utomo, C. E. W., \& Hariadi, M. (2016). Strategi Pembangunan Smart City dan Tantangannya bagi Masyarakat Kota. Jurnal Strategi Dan Bisnis, 4(2), 159$176 . \quad$ Retrieved from http://repository.unej.ac.id/bitstream/handle/123456789/79312/4.

Chandra.pdf?sequence $=1$

Winarno, Budi. (2007). Kebijakan Publik : Teori dan Proses. Yogyakarta : Med Press 